\title{
Detection of myocardial oedema with the use of diffusion-weighted imaging in acute myocardial infarction
}

\author{
Anna Kociemba ${ }^{1 *}$, Magdalena Lanocha', Katarzyna Katulska², Andrzej Siniawski ${ }^{1}$, Magdalena Janus², \\ Stefan Grajek², Malgorzata Pyda²
}

From 2011 SCMR/Euro CMR Joint Scientific Sessions

Nice, France. 3-6 February 2011

\section{Introduction}

MR diffusion-weighted imaging is an important application for oedema detection in various tissues. Evaluation of the area at risk in reperfused acute myocardial infarction (AMI) is currently performed with STIR T2-weighted and LGE sequences.

\section{Purpose}

The aim of the study was to find practical application for a new diffusion-weighted sequences in evaluation myocardial oedema and compare it with routinely used STIR-T2 techniques.

\section{Methods}

In preliminary study myocardial oedema in 15 patients (13 male) with STEMI within 2-4 days were evaluated . The CMR examination was performed on a 1,5 T scanner (Magnetom Avanto; Siemens; Germany; Erlangen;) using a 8-channel phased-array coil. The parameters of the diffusion-weighted EPI sequence (DWI) were as follows: slice thickness $10 \mathrm{~mm}$, repetition time (depending on patient breath cycle) $3-4 \mathrm{~s}$, echo time $78 \mathrm{~ms}$, bandwidth $1,736 \mathrm{~Hz} / \mathrm{Px}$. The DW sequence was ECG-gated and synchronized to the respiratory cycle using PACE technique. Each slice was acquired with $b=50 \mathrm{~s} / \mathrm{mm} 2$, $400 \mathrm{~s} / \mathrm{mm} 2$ and $800 \mathrm{~s} / \mathrm{mm} 2$ with three perpendicular directions of the diffusion gradient. DW, STIR T2-weighted and LGE images were obtained in 2-chamber, 4-chamber or short-axis planes. Images were analysed quantitatively, contrast to noise ratio (CNR) of high signal (oedema) to healthy myocardium (CNR1)

\footnotetext{
${ }^{1} 1$ 'st Clinical Hospital, University of Medical Sciences, Poznan, Poland Full list of author information is available at the end of the article
}

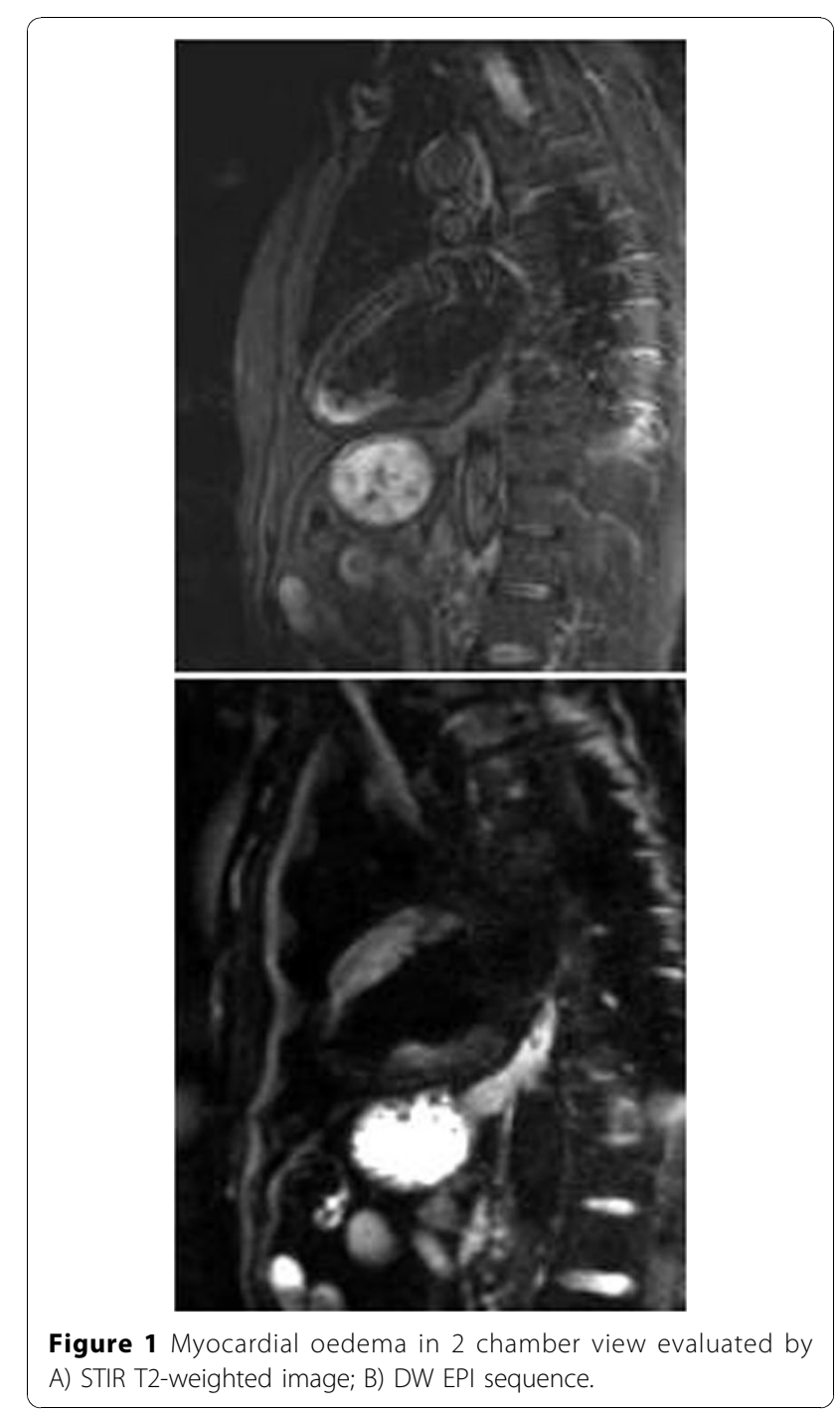

Figure 1 Myocardial oedema in 2 chamber view evaluated by A) STIR T2-weighted image; B) DW EPI sequence. 
and high signal to blood (CNR2) were calculated. For statistical analysis a non parametric Wilcoxon test with significance level of $\mathrm{p}<0,05$ was used.

\section{Results}

The CNR were significantly higher on DWI than on STIR T2-weighted images: CNR1 (22 \pm 7 vs $12 \pm 8 \mathrm{p}=$ 0,004 , respectively)and CNR2 ( $28 \pm 10$ vs $21 \pm 9, \mathrm{p}=0,02$, respectively).

\section{Conclusions}

Our study confirms DW EPI is feasible sequence for myocardial oedema detection with even better contrast to noise ratio than standard STIR T2 sequences.

\section{Author details}

1 1'st Clinical Hospital, University of Medical Sciences, Poznan, Poland.

${ }^{2}$ Poznan University of Medical Science, Poznan, Poland.

Published: 2 February 2011

Cite this article as: Kociemba et al:: Detection of myocardial oedema

with the use of diffusion-weighted imaging in acute myocardial

infarction. Journal of Cardiovascular Magnetic Resonance 2011 13(Suppl 1):

P98.

Submit your next manuscript to BioMed Central and take full advantage of:

- Convenient online submission

- Thorough peer review

- No space constraints or color figure charges

- Immediate publication on acceptance

- Inclusion in PubMed, CAS, Scopus and Google Scholar

- Research which is freely available for redistribution

Submit your manuscript at www.biomedcentral.com/submit 